\title{
Complications of Fracture Treatment by Traditional Bonesetters in West Java, Indonesia
}

\author{
Putri Liana Warman, ${ }^{1}$ Yoyos Dias Ismiarto, ${ }^{2}$ Undang Ruhimat ${ }^{3}$ \\ ${ }^{1}$ Faculty of Medicine Universitas Padjadjaran, ${ }^{2}$ Department of Orthopaedi and Traumatology \\ Faculty of Medicine Universitas Padjadjaran/Dr. Hasan Sadikin General Hospital Bandung, \\ ${ }^{3}$ Department of Radiology Faculty of Medicine Universitas Padjadjaran/ Dr. Hasan Sadikin \\ General Hospital Bandung, Indonesia
}

\begin{abstract}
Background: Traditional medicine practices are still occurring especially in developing countries such as Indonesia. One of the traditional practitioners is the traditional bonesetter (TBS). Due to lack of knowledge of human anatomy, physiology, infection prevention and control, the practices of the TBS has a risk to increase the complications in fractured patients. The objectives of this study was to identify the complications of fractured patients treated by the TBS who were admitted to dr. Hasan Sadikin General Hospital in West Java, Indonesia

Methods: This descriptive study involved 86 medical records of fractured patients admitted to the hospital, from January to December 2014. The collected data were gender, age, admission time after occurrence of the fracture, site of the fracture and early or delayed complications. Moreover, those data were analyzed and presented using frequency tabulation.

Results: Out of 86 patients; 61 (70.93\%) were males; 16 (18.60\%) were 21-30 years old; 25 (29.07\%) had fractures 1-3 months before admitted to the hospital; $83(96.51 \%)$ had closed fractures. There were 86 patients with 109 fractures location; 66 (76.74\%) had fractures in one location; 41 (37.61\%) had femoral fractures. Half of the patients had malunion.

Conclusions: The most complication is malunion.
\end{abstract}

Keywords: Fracture, malunion, traditional bonesetter

\section{Introduction}

A fracture is the structural discontinuity of a bone. ${ }^{1}$ The treatment of fractures is carried out by the orthopaedic practitioners by reduction and immobilization. ${ }^{2}$ Nevertheless, people in developing countries are still looking for traditional healers to solve their health problems including fractures. These traditional healers are called traditional bonesetters (TBS) or dukun patah tulang.,4

There are many factors that cause people choose the TBS instead of doctors, among others, suggested by friends or close relatives, perception of the society that bonesetters are better than doctors in treating fractures, cost of treatment, accessibility, cultural beliefs and fear of surgery. ${ }^{5,6}$
Most of the fractured patients with a history of TBS treatment were admitted to the health care units with complications. The results of TBS practice are often poor, in fact it can cause disability in patients. ${ }^{7}$ This happens because the TBS does not have the knowledge of human anatomy, physiology, radiology, and also infection prevention and control. ${ }^{6}$

Most of the fractures treated by TBS occurred in upper and lower extremities. ${ }^{8}$ The long-term effects that occur as the result of complications greatly affects the quality of life due to disability especially when it occurs in the lower extremities. ${ }^{7}$ Therefore, the objectives of this study was to identify the complications of fracture treatment by TBS admitted to Dr. Hasan Sadikin General Hospital, West Java, Indonesia.

Correspondence: Putri Liana Warman, Faculty of Medicine, Universitas Padjadjaran, Jalan Raya Bandung-Sumedang Km.21, Jatinangor, Sumedang, Indonesia, Email: putrilianawarman@gmail.com 


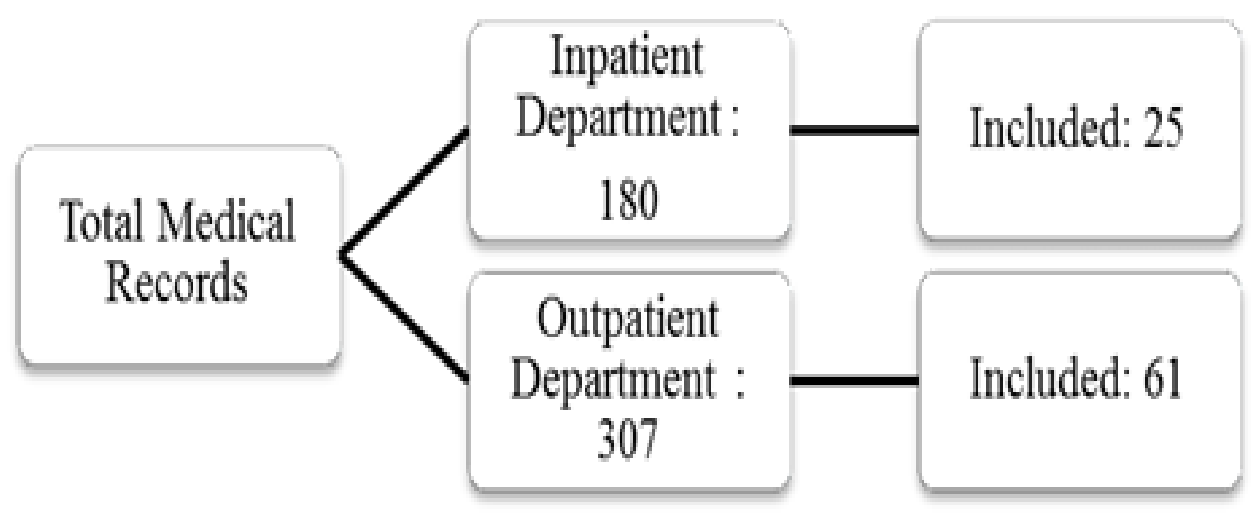

Figure Total Medical Records that Met the Inclusion Criteria

\section{Methods}

A quantitative decriptive study was carried out using medical records of fractured patients admitted to Dr Hasan Sadikin General Hospital from January to December 2014. The total medical records collected were 307 and 180 medical records from the outpatient and inpatient departments respectively. From those medical records, only 86 medical records met the inclusion criteria. Patients with additional treatment history after the patients came to TBS were excluded.

Patients data, such as gender, age, date of fracture, date of admission, site of fracture, and complications occured were taken from medical records. The type of complications was divided into early and delayed complications. The collected data were analyzed using computer and presented by frequency tabulation. This study was approved by the Health Research Ethics Committee, Faculty of Medicine, Universitas Padjadjaran/ Dr. Hasan Sadikin General Hospital Bandung number LB.04.01/A05/EC/260/VII/2015.

\section{Results}

This study discoverd that out of 86, 63 patients $(73.26 \%)$ were males. Patients had the variative range of age from 1 to 79 years. The majority of patients fell within the age range $21-30$ years $(18.60 \%)$. Each patient had different chronicity which were seen from the length of time, from the date of fractures to the admission time. Most of the patients were admitted to the hospital in 1-3 months $(29.07 \%)$ after the fractures occurred. In this study, there were 86 fractured patients with 109 locations of fracture. Most of the patients had closed fractures (96.51\%) and had fractures in one location $(76.74 \%)$, and seventy one $(37.61 \%)$ of fractures were femoral fractures (Table 1).

Regarding complications, most of the patients had only one complication, and delayed complications with malunion as the most common complication. (Table 2).

Early complications were neurologic impairment, compartment syndrome, gangrene, soft tissue injury, wound infection, and sepsis. Delayed complications were avascular necrosis, chronic osteomyelitis, malunion, nonunion, joint stiffness, delayed union, secondary osteoarthritis, muscle atrophy, and Volksmann contracture.

\section{Discussions}

This study discovered that most of the fractured patients treated by the TBS were predominantly male. This result correlated with previous studies, which stated that the majority of fractured patients were male. ${ }^{7,9}$ Regarding age, the majority of patients were in their productive age. These findings were similar to a study in Nigeria by Onymaechiet et al. ${ }^{8}$ who described the average age was 36.8 years and by Dada et al. ${ }^{10}$ with the average age 29.49 years. In this study the male and productive age being preponderance correlated with the higher mobilization of males during the productive age which 


\begin{tabular}{|c|c|c|}
\hline Characteristics & Frequency $(n=86)$ & Percentage (\%) \\
\hline \multicolumn{3}{|l|}{ Sex } \\
\hline Female & 23 & 26.74 \\
\hline Male & 63 & 73.26 \\
\hline Age & 86 & 100.00 \\
\hline$<10$ years & 10 & 11.60 \\
\hline $11-20$ years & 15 & 17.40 \\
\hline $21-30$ years & 16 & 18.60 \\
\hline $31-40$ years & 14 & 16.30 \\
\hline $41-50$ years & 12 & 14.00 \\
\hline $51-60$ years & 13 & 15.10 \\
\hline $61-70$ years & 4 & 4.70 \\
\hline $71-80$ years & 2 & 2.30 \\
\hline \multicolumn{3}{|l|}{ Admission Time } \\
\hline$<1$ week & 7 & 8.14 \\
\hline 1 week $-<1$ month & 10 & 11.63 \\
\hline $1-3$ months & 25 & 29.07 \\
\hline $4-6$ months & 15 & 17.44 \\
\hline 7-9 months & 7 & 8.14 \\
\hline $10-12$ months & 8 & 9.30 \\
\hline$>12$ months & 14 & 16.28 \\
\hline \multicolumn{3}{|l|}{ Type of Fracture } \\
\hline Closed & 83 & 96.51 \\
\hline Open & 3 & 3.49 \\
\hline \multicolumn{3}{|l|}{ Number locations of fracture } \\
\hline 1 site & 66 & 76.74 \\
\hline 2 sites & 17 & 19.77 \\
\hline 3 sites & 3 & 3.49 \\
\hline Site of Fracture & $\mathrm{n}=109$ & \\
\hline \multicolumn{3}{|l|}{ Upper extremities } \\
\hline Humerus & 9 & 8.26 \\
\hline Radius & 10 & 9.17 \\
\hline Ulna & 3 & 2.75 \\
\hline Hand & 3 & 2.75 \\
\hline \multicolumn{3}{|l|}{ Lower exstremities } \\
\hline Femur & 41 & 37.61 \\
\hline Tibia & 21 & 19.27 \\
\hline Fibula & 16 & 14.68 \\
\hline Foot & 6 & 5.50 \\
\hline
\end{tabular}


Table 2 Distribution of Fracture Complications Due to Bonesetter Treatment

\begin{tabular}{|c|c|c|c|c|}
\hline \multirow{3}{*}{ Characteristics } & \multirow{2}{*}{\multicolumn{2}{|c|}{$\begin{array}{l}\text { Outpatients } \\
\text { (Orthopaedic and Traumatology } \\
\text { Clinics) }\end{array}$}} & \multicolumn{2}{|c|}{ Inpatient } \\
\hline & & & \multirow{2}{*}{$\begin{array}{c}\text { From } \\
\text { Emergency } \\
\text { Unit }\end{array}$} & \multirow{2}{*}{$\begin{array}{l}\text { From Clinics } \\
\text { Frequency (n) }\end{array}$} \\
\hline & Frequency (n) & $\begin{array}{c}\text { Percentage } \\
(\%)\end{array}$ & & \\
\hline Number of Complication & $n=61$ & & $n=6$ & $\mathrm{n}=19$ \\
\hline 1 complication & 34 & 55.74 & 4 & 14 \\
\hline 2 complications & 14 & 22.95 & 2 & 2 \\
\hline$>2$ complications & 1 & 1.64 & 0 & 1 \\
\hline No complication & 12 & 16.67 & 0 & 2 \\
\hline Type of Complication & $\mathrm{n}=64$ & & $\mathrm{n}=8$ & $n=21$ \\
\hline Early complication & 5 & 7.81 & 3 & 4 \\
\hline Delayed complication & 59 & 92.19 & 5 & 17 \\
\hline Complication & $\mathrm{n}=64$ & & $\mathrm{n}=8$ & $\mathrm{n}=21$ \\
\hline Wound Infection & 0 & 0 & 1 & 1 \\
\hline Compartment Syndrome & 0 & 0 & 1 & 1 \\
\hline Neurologic Impairment & 5 & 7.81 & 0 & 0 \\
\hline Gangrene & 0 & 0 & 1 & 1 \\
\hline Sepsis & 0 & 0 & 0 & 1 \\
\hline Joint Stiffness & 6 & 9.38 & 1 & 1 \\
\hline Avascular Necrosis & 1 & 1.56 & 0 & 1 \\
\hline Chronic Osteomyelitis & 1 & 1.56 & 0 & 1 \\
\hline Soft Tissue Injury & 1 & 1.56 & 0 & 1 \\
\hline $\begin{array}{l}\text { Mal-union(Shortening. } \\
\text { angulation, and rotation) }\end{array}$ & 35 & 54.69 & 3 & 10 \\
\hline Delayed union & 1 & 1.56 & 0 & 0 \\
\hline Non-union & 12 & 18.75 & 0 & 2 \\
\hline Secondary Osteoarthritis & 1 & 1.56 & 0 & 1 \\
\hline Muscle atrophy & 1 & 1.56 & 0 & 0 \\
\hline Volksmann Contracture & 0 & 0 & 1 & 0 \\
\hline
\end{tabular}

can make the higher risk of fractures, as the most common etiology of fracture is traffic accident. $4,7,9$

Closed fractures are the type of fractures mostly treated by the TBS. ${ }^{10}$ This situation was also discovered in this study. This phenomenon occurred because most of the TBS refused to treat patients with open 
fractures and preferred to refer those patients to the hospitals. ${ }^{3}$

This study discovered that the most frequent complication was malunion, followed by nonunion. Similar studies conducted in Nigeria and at Dr. Abdoer Rahem hospital, East Java gave the same results. ${ }^{7,10}$ In Europe ${ }^{11}$ and many developed countries that suppressed traditional medicine practices, the most complication occurred in fractured patients treated by doctors was post-surgical infection. ${ }^{1}$

Those complications after the TBS treatment occurred due to the method used in managing fractures. The methods used by the TBS are massage, splinting, and traction of the fracture area. These methods can cause a shift in the area of the fractures. ${ }^{10,12,13}$ Splinting performed by the TBS, using bamboo or palm branches is often too tight, so it can cause gangrene. ${ }^{10,14}$ In this study, 2 patients had gangrene. Gangrene is the most severe complication and can lead to death. 8,10

Furthermore, femoral fractures were the most common site of fracture, which differs from the previous study, as tibial fractures had the greatest number. ${ }^{8}$ The location of femur is deeper than tibia because the femur is covered by thick muscles and fat tissues. It can cause the massage and splinting conducted by the TBS may not be an effective treatment for femoral fractures. Moreover, this causes a greater risk of complications in femoral fractures compared to other sites of the extremities.

This study has some limitations. The process of fracture healing includes many factors among others age, previous medical history, and nutrition. In this study those factors were not considered, so the complications occurred merely because of mismanagement by the TBS.

It can be concluded that the most common complication is malunion Early complications are neurologic impairment, compartment syndrome, gangrene, soft tissue injury, wound infection, and sepsis. Delayed complications are avascular necrosis, chronic osteomyelitis, malunion, nonunion, joint stiffness, delayed union, secondary osteoarthritis, muscle atrophy, and Volksmann contracture

\section{References}

1. Nayagam S, Salomon, Louis., Warwick, David. Apley`s System of Orthopaedics and Fractures. $9^{\text {th }}$ ed. London: Hodder Arnold; 2010.
2. Adi Mahartha GR, Maliawan S, Kawiyana KS. Management of fracture of musculosceletal trauma. E-journal Medika Udayana. 2013;2(3):548-60.

3. Nwachukwu BU, Okwesili IC, Harris MB, Katz JN. Traditional bonesetters and contemporary orthopaedic fracture care in a developing nation: historical aspects, contemporary status and future directions. Open Orthop J. 2011;5(1):20-5.

4. Sari AP, Priambodo A, Pramono D. Faktor-faktor yang berhubungan dengan keterlambatan berobat pada pasien patah tulang yang menggunakan sistem pembiayaan jamkesmas (Studi Kasus di RSUP Dr. Kariadi Semarang Tahun 2012). Medico. 2012;1(1):1-13.

5. Ekere A, Echem R. Patronage of traditional bone setters for musculoskeletal conditions: A one-year study. Port Harcourt Med J. 2012;6(2):215-24.

6. Onyemaechi NO, Lasebikan OA, Elachi IC, Popoola SO, Oluwadiya KS. Patronage of traditional bonesetters in Makurdi, NorthCentral Nigeria. Patient Pref Adherence. 2015;9(1):275-9.

7. Wahyudiputra AG, Khoirur HD, Hakim RA, Narendra MR. Spektrum Penderita Neglected Fracture di RSUD dr. Abdoer Rahem-Januari 2012 s/d Desember 2013. CDK. 2015;42(2):97-100.

8. Onyemaechi NOC. Complications of musculoskeletal injuries treated by traditional bonesetters in a developing country. Indian J Appl Res. 2014;4(3):3136.

9. Owumi B, Taiwo PA, Olorunnisola A. Utilization of traditional bone-setters in the treatment of bone fracture in Ibadan North Local Government. Int J Humanities Soc Science Invention. 2013;2(5):47-57.

10. Dada A, Giwa S, Yinusa W, Ugbeye M, Gbadegesin S. Complications of treatment of musculoskeletal injuries by bone setters. West Afr J Med. 2009;28(1):333-7.

11. Selin H. Encyclopaedia of the History of Science, Technology, and Medicine in NonWestern Cultures. 2nd ed. Massachusetts: Springer Science \& Business Media; 2013.

12. Eze KC. Complications and co-morbidities in radiographs of patients in traditional bone setters' homes in Ogwa, Edo State, Nigeria: a community-based study. Eur J Radiol. 2012;81(9):2323-8.

13. Chowdhury M, Khandker H, Ahsan K, Mostafa D. Complications of fracture 
treatment by traditional bone setters at Dinajpur. Dinajpur Med Col J. 2011;4(1):15-9.

14. Panda AK, Rout S. Puttur kattu (bandage)-a traditional bone setting practice in South India. J Ayurveda Integr Med. 2011;2(4):174-8. 